\title{
Bimetallic Copper-Heme-Protein-DNA Hybrid Catalyst for Diels Alder Reaction ${ }^{\dagger}$
}

\author{
Chi-Hsien Kuo, ${ }^{\text {b,c }}$ Christof M. Niemeyer, ${ }^{\text {b }}$ and Ljiljana Fruk, ${ }^{\text {a,* }}$ \\ ${ }^{a}$ DFG-Centre For Functional Nanostructures, Karlsruhe Institute of Technology, \\ Wolfgang Gaede Str. 1a, 76131 Karlsruhe, Germany \\ ${ }^{\mathrm{b}}$ Technische Universität Dortmund, Fakultät Chemie, Biologisch-Chemische Mikrostrukturtechnik, \\ Otto-Hahn Str. 6, D-44227 Dortmund, Germany \\ ${ }^{\circ}$ Institute of Chemistry, Academia Sinica, 128 Academia Road Scc. 2, Nankang, Taipei 11529, Taiwan
}

\begin{abstract}
A bimetallic heme-DNA cofactor, containing an iron and a copper center, was synthesized for the design of novel hybrid catalysts for stereoselective synthesis. The cofactor was used for the reconstitution of apo-myoglobin. Both the cofactor alone and its myoglobin adduct were used to catalyze a model Diels Alder reaction. Stereoselectivity of this conversion was analyzed by chiral HPLC. Reactions carried out in the presence of myoglobin-heme-Cu-DNA catalyst showed greater product conversion and stereoselectivity than those carried out with the heme-Cu-DNA cofactor. This observation suggested that the protein shell plays a significant role in the catalytic conversion.(doi: 10.5562/cca1828)
\end{abstract}

Keywords: bioorganic chemistry, DNA-protein conjugates, stereoselective catalysis

\section{INTRODUCTION}

One of the ongoing challenges in synthetic chemistry concerns the development of powerful catalysts. Of particular interest is the use of highly selective and efficient enzymes as biocatalysts for chemical synthesis. Our increased understanding of chemical and enzymatic catalysis has enabled us to explore and develop bio inspired catalysts with modified, even enhanced efficiency and selectivity by taking advantage of a variety of enzyme classes. ${ }^{1}$ For example, metalloenzymes, which contain a metal ion cofactor as prosthetic group are an important class of proteins involved in a range of biologically important reactions such as substrate oxidation (cytochrome P450 enzymes, peroxidases), ${ }^{2}$ carbon dioxide fixation (carbonic anhydrase),superoxide dismutation $^{3}$ and many others. It is estimated that one third of all enzymes require a metal cofactor to ensure proper function and as a result, numerous studies are devoted to the understanding of their structure and function. ${ }^{4}$

Owing to the advances in biophysical and computational chemistry as well as in structural biology, it is nowadays possible to design new hybrid metalloenzymes with enhanced stability and reaction efficiency. This is achieved either by modification of theprotein shell through introduction of unnatural amino acids ${ }^{5}$ or by replacing metal containing prosthetic groups with artificial ones. ${ }^{6}$ Since tailoring of the protein shell often requires lengthy process of site selective mutations and subsequent enzyme expression, this approach is often of limited because of the low amounts of the biocatalyst that can be produced. ${ }^{5}$

On the other hand, the modification of small organic prosthetic group offers ease of preparation and a range of different functions, which can be introduced. By chemical modification of prosthetic groups such as protophorphyrin IX (heme) and their insertion into apo-enzymes (that are non active enzymes which lack their natural prosthetic group), highly efficient catalysts with novel properties can be obtained. ${ }^{7}$ For example, the reconstitution of apo-myoglobin (apoMb) with ruthenium (II) modified heme led to the development of photoactivatable enzymes, which enable temporal control over oxidation reactions catalyzed by myoglobin. ${ }^{8}$ But the changes in the metalloenzyme prosthetic group are not the only approach to evolve interesting new catalytic properties. Introduction of a catalytic moiety into the chiral environment of a host protein can also lead to novel enantionselective catalysts that are active under mild conditions and show high selectivity. ${ }^{9}$ In one of the first examples, Wilson and Whitesides performed enantioselective hydroge-

\footnotetext{
$\dagger$ This article belongs to the Special Issue Chemistry of Living Systems devoted to the intersection of chemistry with life.

* Author to whom correspondence should be addressed. (E-mail: Ljiljana.fruk@kit.edu)
} 
nation with avidin as a chiral protein host and biotinylated phosphine rhodium (I) nornborndiene complex as the catalytic centre. This approach led to $40 \%$ of enantiomeric excess (e.e.) values. ${ }^{10}$ The initially described ligands, ${ }^{10}$ such as phosphine rhodium complexes were later replaced by other metal complexes yielding even higher (up to $96 \%$ ) e.e. values and increased catalytic turnover. ${ }^{9,11}$ These results clearly indicate that hybrid metal-protein complexes hold great potential as catalysts in synthetic organic chemistry. Building upon this idea, Reetz et al designed hybrid proteins by non-covalent attachment of $\mathrm{Cu}$-phtalocyanine to different serum albumins. ${ }^{12}$ Such proteins were capable of catalyzing Diels Alder reaction of azachalcones with cyclopentadiene in aqueous medium with high selectivity and e.e. between 85-93\% depending on the albumins used. Such high e.e. clearly indicated the potential of the protein modification for design of powerful hybrid catalysts. In the further work by the same group, thermostable protein tHIsF was modified by site specific mutagenesis to enable $\mathrm{Cu}^{2+}$ binding thereby affording an artificial metalloenzyme. ${ }^{13}$ The hybrid enzyme achieved $46 \%$ e.e. in Diels Alder reaction showing that the rational introduction of catalytic groups to the natural proteins can lead to a design of novel catalysts, however some issues of site directed mutagenesis and catalytic selectivity need to be resolved.

Recently, DNA has also been used as a chiral support for enantioselective catalysts because of its chemical stability and well defined structure. ${ }^{14,15}$ In addition, DNA from natural sources such as salmon sperm or calf thymus, can be obtained in relatively large quantities compared to the proteins. DNA could also enable rational design of the desired catalytic centre as numerous metal binding functional groups with huge catalytic potential can be introduced to the natural systems. As an example, taking advantage of the ability of certain functional groups to intercalate the double-stranded DNA, Roelfes et al. designed $\mathrm{Cu}^{2+}$ complex which, when bound to the DNA, revealed good enantioselectivity in Diels Alder reaction. ${ }^{14 a, 14 b}$ Similar hybrid catalytic systems based on DNA and $\mathrm{Cu}$ complexes were also used for other reactions such as Friedel Crafts alkylation ${ }^{16}$ and Michael addition. ${ }^{17}$ In previous work we have shown that functional DNA-heme protein conjugates as well as photoactivatable enzymes can be generated by reconstitution of apoMb with chemically modified heme derivatives. ${ }^{18}$ Motivated by the aforementioned developments of hybrid metalloenzyme catalysts, we here demonstrate for the first time that the reconstitution of apoMb with a bimetallic heme cofactor can be used to create novel catalysts for stereoselective synthesis. In particular, we report on the synthesis of an artificial heme group containing a singlestranded DNA oligonucleotide as well as an appended $\mathrm{Cu}$ (II) moiety, which was successfully used for reconstitution of apoMb. The resulting hybrid was used as a cata- lyst in a model Diels-Alder reaction revealing moderate stereoselectivity as a consequence of the chiral environment provided by both the DNA and protein shell.

\section{RESULTS AND DISCUSSION}

Modification of heme moiety and its reconstitution into apo enzymes has been successfully used as a tool for introducing new functionalities to the heme enzymes. ${ }^{6}$ In such way novel biomaterials were designed by use of DNA- ${ }^{19}$ and polymer modified heme groups. ${ }^{20}$ In many cases, enhanced catalytic performance was enabled by modification of the heme propionate groups, ${ }^{21}$ exchange of iron centre ${ }^{22}$ or by appending electro- ${ }^{23}$ and photoactive $^{8,24}$ groups to these side chains. Inspired by the work of Hamachi et al. ${ }^{24}$ on photoactivatable $\mathrm{Mb}$, we have previously synthesized tris (2, 2'-bipyridyl)ruthenium (II) $\mathrm{Ru}(\mathrm{bpy})_{3}{ }^{2+}$-DNA heme conjugate, in which the $\mathrm{Ru}$ moiety is used for the photoactivation of the artificial catalyst while the DNA moiety can be harnessed for selective hybridization-based immobilization. ${ }^{18}$ Herewith we show that a similar synthetic route can be used to synthesize a heme derivative chemically modified with a $\mathrm{Cu}(\mathrm{bpy})^{2+}$ moiety to provide active centre for the catalysis of Diels-Alder reaction.

5' alkylamino modified oligonucleotide 1, which remained bound on the controlled pore glass (CPG) support after solid-phase phosphoamidite synthesis was reacted with heme in the presence of HBTU/HOBt/DIPEA (HBTU $=O$-benzotriazole- $N, N$ ', $N$ ' '-tetramethyl-uronium hexafluorophosphate, $\mathrm{HOBt}=1$-hydroxybenzotriazole, DIEA = diisopropylethylamine) as activating agents for amide coupling. ${ }^{6}$ As a result, two products are formed, namely heme derivatives where one or both propionic groups are modified with a DNA strand ( 2 and $\mathbf{3}$ respectively in Figure 1).

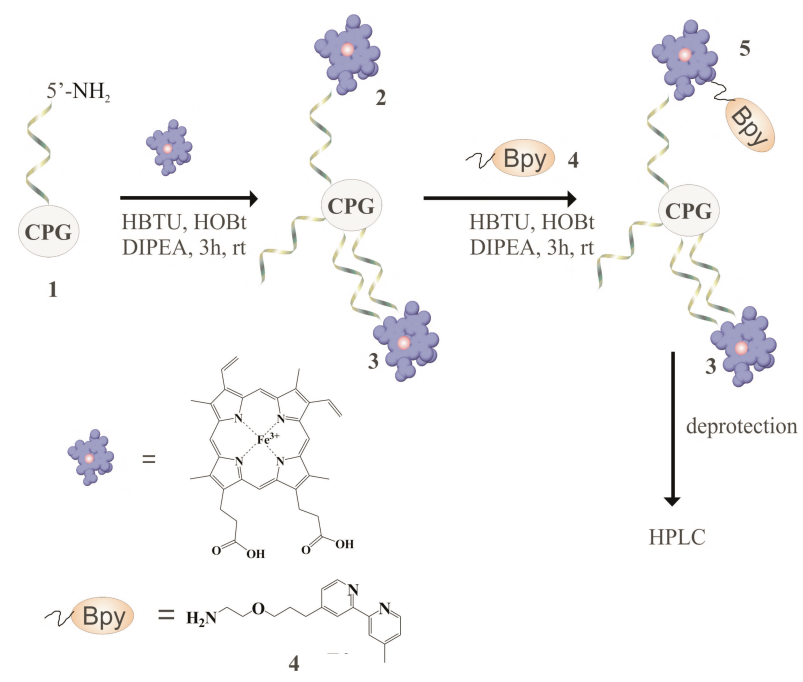

Figure 1. Schematic representation of the Byp-heme-DNA synthesis using solid phase synthetic procedure. 


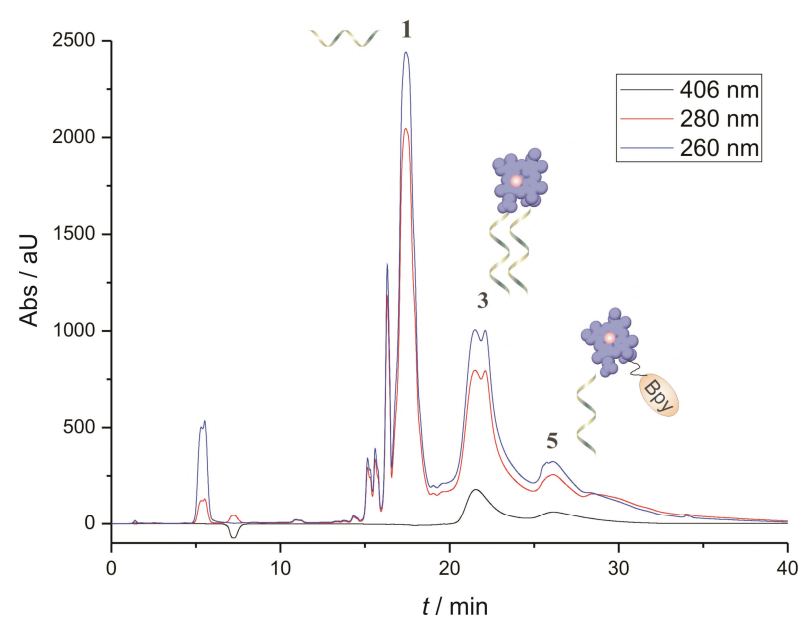

Figure 2. Chromatogram of HPLC analysis of modified heme purification after cleavage and deprotection from CPG solid support.

The CPG was then washed and reacted with an access of amino-bpy $\mathbf{4}$, synthesized according to a previously reported procedure, to yield heme derivative $\mathbf{5}$ (Figure 1). Subsequent to the cleavage from the $\mathrm{CPG}$ support using $t$-butylamine $/ \mathrm{meOH} /$ water treatment at $65{ }^{\circ} \mathrm{C}$, the crude reaction mixture was analyzed and purified by high performance liquid chromatography (HPLC). Besides the unreacted DNA (1) and the byproduct HemeD $\mathbf{H}_{2}$ (3), the desired bpy-hemeD $\mathbf{1}$ (5) complex was obtained(Figure 2). The reaction yield was about $10 \%$ with respect to the used amount of DNA, which is in good agreement with earlier studies. ${ }^{18}$

In addition to HPLC characterization, the presence of the expected product 5 was also confirmed by MALDI-MS analysis (Figure S1), which revealed an observed mass peak at $\mathrm{m} / \mathrm{z}=7937$, corresponding to $\left[\mathrm{M}+\mathrm{NH}_{4}\right]^{+}$. Byp-hemeD ${ }_{1} 5$ was then incubated with 10 equivalents of $\mathrm{Cu}\left(\mathrm{NO}_{3}\right)_{2}$ to afford $\mathrm{Cu}(\text { byp })^{2+}$-hemeD $\mathrm{D}_{1} 6$ (Figure $3 \mathrm{a}$ ) and the product was purified by gel filtration chromatography to remove excess of the inorganic salt. MALDI-MS analysis indicated complete conversion (peak at $m / z=7983$, corresponding to $[\mathrm{M}+2 \mathrm{H}]^{+}$(Figure 3b).

To investigate the effect of the DNA strand on the enantioselective catalysis, $\mathrm{Cu}$ (byp)-heme $\mathrm{D}_{1}$ was hybridized with its complementary strand to form double stranded, chiral conjugate $\mathrm{Cu}$ (byp)-heme $\mathrm{D}_{1} \mathrm{cD}_{1} 7$ (Figure 4a). The hybrid was then used as the catalyst for Diels Alder reaction between dienophile 3-phenyl-1-(2pyridyl)-2-propen-1-one 8 and cyclopentadiene $\mathbf{9}$, which was previously shown to be catalyzed by $\mathrm{Cu}^{2+} .{ }^{25}$ Dienophile 8 was prepared by aldol condensation of benzaldehyde with a slight excess of 2-acetylpyridine at $0{ }^{\circ} \mathrm{C}$ in water, as previously reported. ${ }^{26}$

Since $\mathbf{8}$ is a poor dienophile, Diels Alder reaction only occurs in the presence of Lewis acids. ${ }^{25 a}$ In a test a)

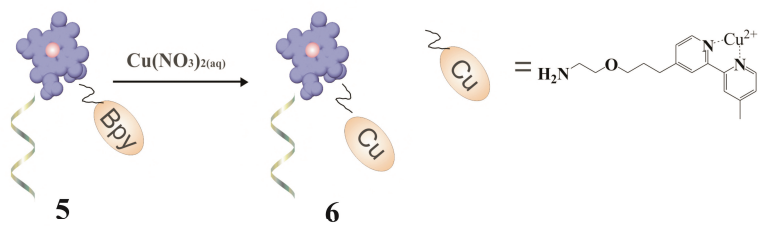

b)

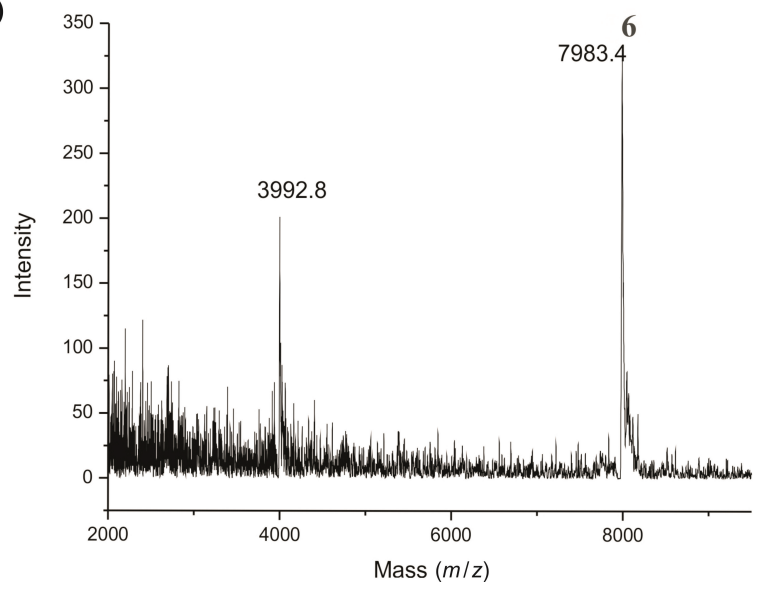

Figure 3. Preparation a) and identification b) of $\mathrm{Cu}(\mathrm{II})$ bypheme- $\mathrm{D}_{1} 6$ conjugate.

reaction, compound $\mathbf{8}$ was first reacted with 9 in presence of $\mathrm{Cu}\left(\mathrm{NO}_{3}\right)_{2}$ salt to afford a racemic mixture of endo (major compund $\mathbf{1 0} \mathbf{a}$ and b) and exo (minor, compound 11a and b) isomers (Figure S2). Chiral HPLC analysis of the reaction products revealed that four major products were formed, corresponding to the exo (11) and endo isomers (10). The endo/exo ratio was 11.4 and, as expected, no e.e. was observed. The retention times of the product peaks were comparable to those of the products of the previously studied Lewis acid catalyzed enantioselective Diels Alder reaction. ${ }^{14 \mathrm{~b}}$

These data were used as a reference for the experiments using $\mathrm{Cu}$ (byp)-heme $\mathrm{D}_{1} \mathrm{cD}_{1}$ conjugate 7 as the catalyst (Figure 4b). Conjugate 7 was obtained from 6 by simple hybridization with one molar equivalent of the complementary ssDNA oligonucleotide. Subsequent to the incubation of the dienophile and diene for 72 hours at $4{ }^{\circ} \mathrm{C}$ in the presence of hybrid 7 , the reaction mixture was analyzed by chiral HPLC. Remarkably, the analysis revealed only two peaks corresponding to the endo adducts, while no exo adduct could be detected (Figure 4c). However, calculation of the product conversion based on the corresponding peak areas showed that the products were only formed in about $6 \%$ yield. Chiral HPLC analysis also revealed that no enantiomeric excess was obtained in the reaction catalyzed by hybrid 7. This might be explained by the fact that the chiral microenvironment of the dsDNA is too far away from the copper centre. 
a)

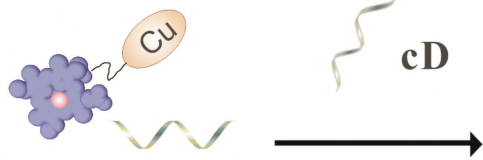

6

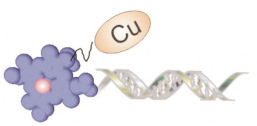

7
(S,S)endo (R, R)<smiles>O=C(/C=C/c1ccccc1)c1ccccn1</smiles>

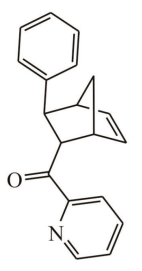

$10 \mathrm{a}$

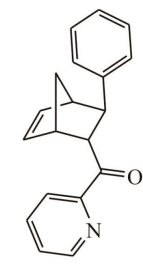

$10 \mathrm{~b}$
(S,S)exo (R,R)

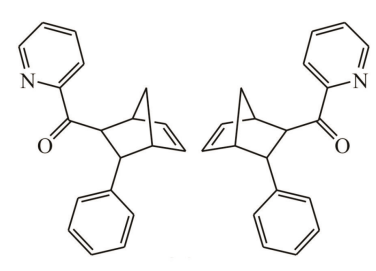

$11 \mathrm{~b}$

c)

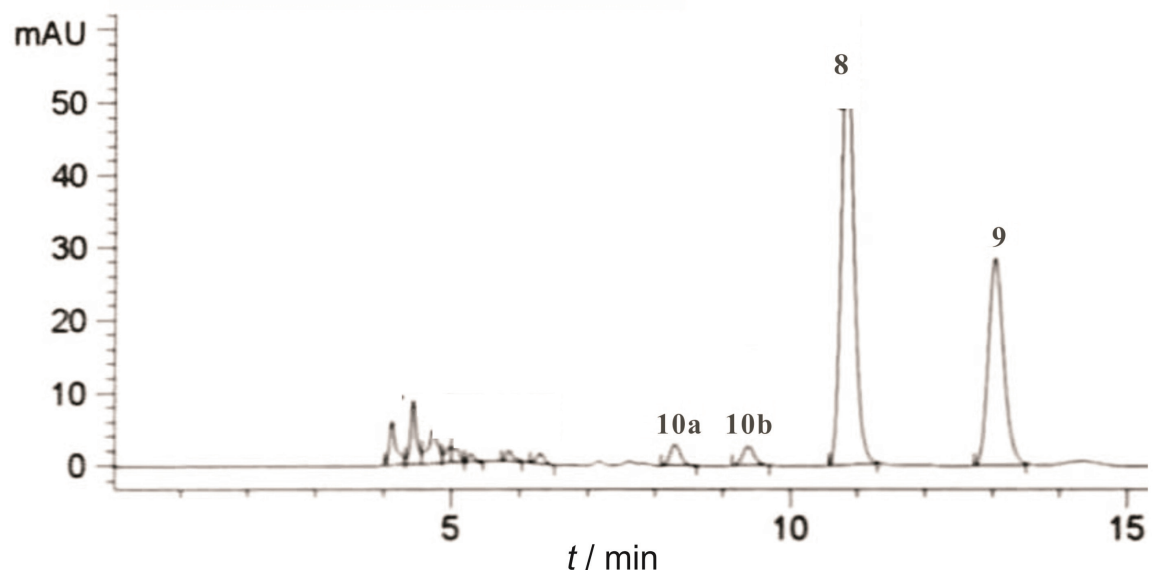

Figure 4. Hybridisation of heme $D_{1} 6$ with complementary DNA strand to afford double stranded conjugate 7 (a), which is then used as a catalyst for Diels Alder reaction (b). Chiral HPLC analysis of Diels Alder adducts catalysed by heme- $\mathrm{D}_{1} \mathrm{cD} 7$ conjugate.

To explore further the effect of biomolecular environment on the stereoselectivity of the catalytic $\mathrm{Cu}$ centre, conjugate $\mathbf{6}$ was used to reconstitute apoMb (Figure 5a), thereby enabling the investigation of potential effects of chiral protein shell. It was expected that the second coordination sphere created by the protein shell should influence the $\mathrm{Cu}^{2+}$ catalyzed Diels Alder reaction since the catalytic metal centre is closely embedded in the chiral microenvironment provided by the protein and ssDNA moieties.

After reconstitution of apoMb with conjugate $\mathbf{6}$, the reaction mixture was analyzed and purified by FPLC using an anion exchange column (Figure 5b). The resulting $\mathrm{Cu}$ (byp)-Mb- $\mathrm{D}_{1}$ conjugate $\mathbf{1 2}\left(0.1 \mathrm{mmol} \mathrm{dm}{ }^{-3}\right)$ was then used as catalyst for Diels Alder reaction under same conditions as described above. The reaction mixture was subjected to the chiral HPLC analysis (Figure 5c). Peaks $11 \mathrm{a}$ and $11 \mathrm{~b}$ refer to the both enantiomers of exo product and peaks $10 \mathrm{a}, \mathrm{b}$ correspond to both enantiomers of the endo product, while peaks 8 and 9 correspond to the educts. The product conversion of about $71 \%$ was significantly higher than observed for the DNA hybrid catalyst 7 . The endo/exo selectivity (8.6) was lower than observed for 7 , however distinctive enantioselectivity could be observed with e.e. values for endo product of $18 \%$ and for exo products of $10 \%$.

These results illustrate that the semisynthetic enzyme $\mathbf{1 2}$ is a far better catalyst than $\mathrm{Cu}$ (byp)heme $\mathrm{D}_{1} \mathrm{cD}_{1}$ 7. Higher product conversion and greater enantioselectivity suggest that the protein shell plays a significant role in the overall catalytic effect. Indeed, the catalytic copper centre is closer to the chiral microenvrionment of the myoglobin. In comparison with previously studied systems of DNA-metal catalytic hybrids 
a)

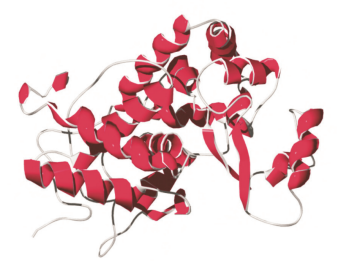

apoMb
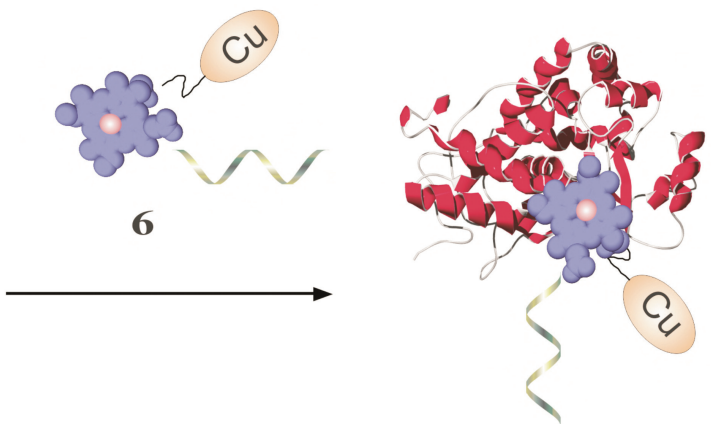

Cu(Bур)-MbD1

12

b)

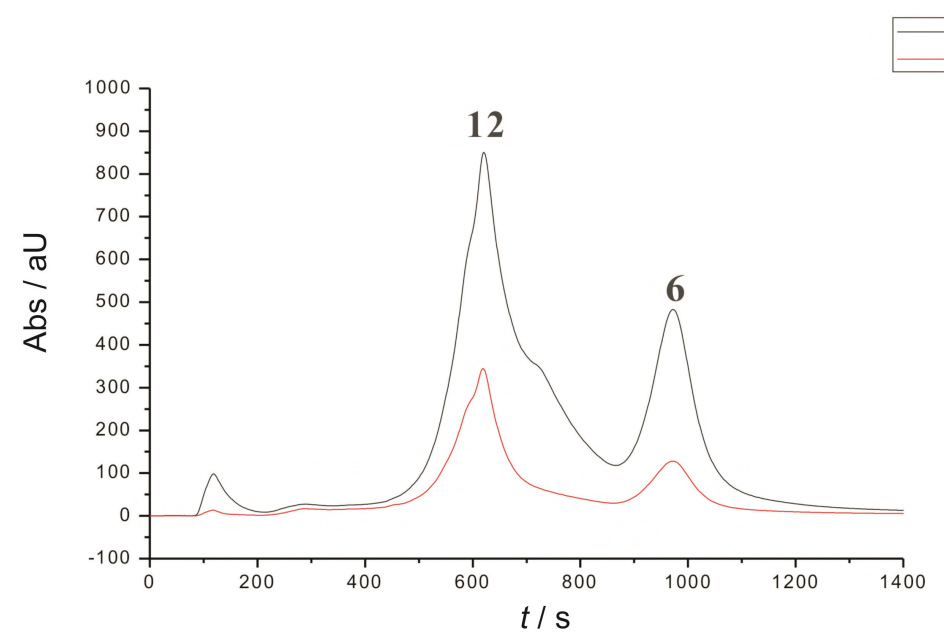

c)

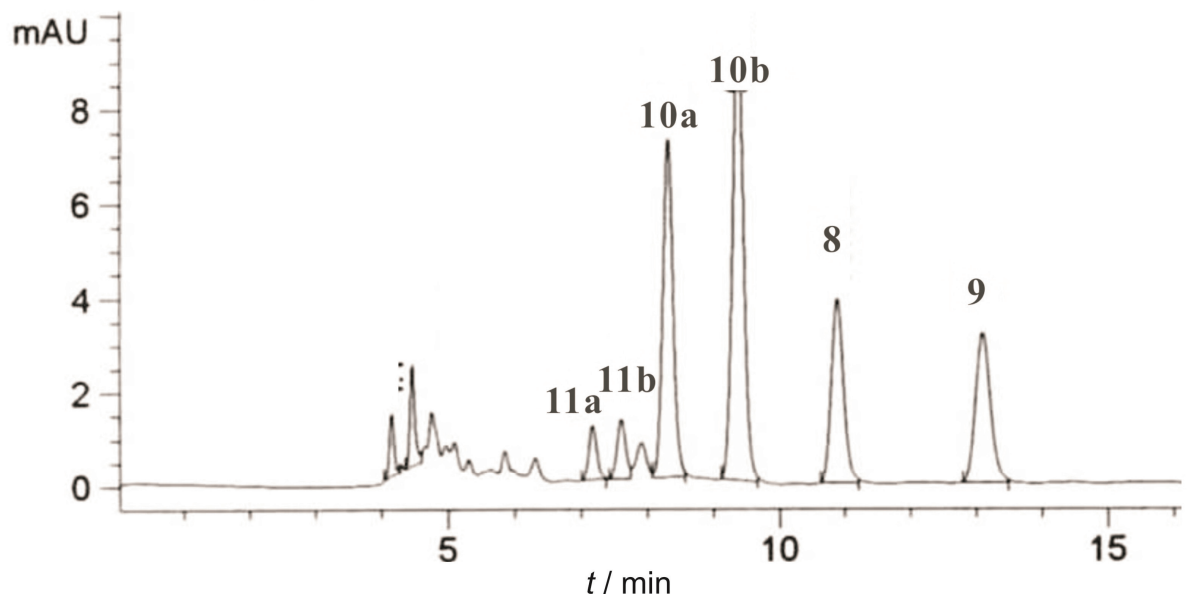

Figure 5. Reconstitution of heme $\mathbf{6}$ into apo myoglobin to prepare hybrid catalyst 12 (a) and subsequent FPLC purification. Diels Alder reaction products were analysed by chiral HPLC (c).

for similar Diels Alder reactions, ${ }^{14}$ however, our semisynthetic protein conjugate were less efficient with respect to the enantioselectivity. Therefore, further work will focus on exploring other protein models where the
$\mathrm{Cu}$ centre is more closely embedded in the protein shell. Moreover, different porphyrins and DNA sequences will be investigated to generate a library of semisynthetic enzyme-DNA catalysts. 


\section{EXPERIMENTAL SECTION}

Copper ligand 4: amno-Bpy 4 was synthesized using modified approach described previously by Hamachi ${ }^{8}$ and Kuo. ${ }^{18}$ Detailed experimental procedures are provided in the Supporting Information

Preparation of bpy-hemeD 1 conjugate 5. Commercially available amino modified oligonucleotide (5' $\mathrm{Tr}$ amino-GTG GAA AGT GGC AAT CGT GAA G), which was still coupled to the CPG support and contained the protection group. The trityl group was manually removed using commercial $3 \%$ dichloroacetic acid (DCA) in dichloromethane solution followed by washing with $\mathrm{CH}_{3} \mathrm{CN}$ and drying with argon. Hemin $(75 \mu \mathrm{mol})$ and HBTU $(75 \mu \mathrm{mol})$ were dissolved in 1.0 $\mathrm{ml} \mathrm{DMF}$ and to this HOBt $(50 \mu \mathrm{mol})$ in $500 \mu \mathrm{L} \mathrm{CH}_{3} \mathrm{CN}$ was added followed by $27 \mu \mathrm{L}$ DiPEA. This solution was mixed with the detritylated oligonucleotide and coupling was allowed to proceed for 180 minutes at $20{ }^{\circ} \mathrm{C}$. The resulting CPG suspension was then washed thoroughly with DMF and $\mathrm{CH}_{3} \mathrm{CN}$ and dried with argon. HOBt $(50 \mu \mathrm{mol})$ and HBTU $(75 \mu \mathrm{mol})$ were dissolved in $1.0 \mathrm{ml} \mathrm{DMF}$ and to this aminoalkyl-modified bipyridine, amino-Bpy $4(75 \mu \mathrm{mol})$ in $500 \mu \mathrm{L} \mathrm{CH}_{3} \mathrm{CN}$ was added followed by $27 \mu \mathrm{L}$ DiPEA. This solution was then incubated at $40{ }^{\circ} \mathrm{C}$ overnight. The modified oligonucleotide was then de-protected using t-butylamine: $\mathrm{MeOH}: \mathrm{H}_{2} \mathrm{O}(1: 2: 1)$ mixture for $3 \mathrm{~h}$ at $65^{\circ} \mathrm{C}$, purified by HPLC and analyzed by MALDI-TOF mass spectrometry.

\section{Preparation of $\mathrm{BpyCu}$-hemeD $_{1}$ conjugate 6:}

$0.1 \mathrm{mmol} \mathrm{dm}^{-3}$ of bpy-hemeD ${ }_{1}$ conjugate 5 was incubated in a $1 \mathrm{mmol} \mathrm{dm}^{-3}$ aqueous solution of $\mathrm{Cu}\left(\mathrm{NO}_{3}\right)_{2}$ at room temperature for 3 hours, to yield $\mathrm{Cu}(\mathrm{bpy})^{2+}$-hemeDNA conjugate. The product was successively purified with NAP 5, NAP 10 columns and Vivaspin ${ }^{\circledR}$ columns (cutoff filter 5000) in order to remove the excess of inorganic salts thoroughly. The conjugate was then analyzed with MALDI-TOF mass spectrometry.

Reconstitution of apo-myoglobin with artificial cofactor. Apo-myoglobin (aMb) was prepared by Teale's 2-butanone method. In brief, the aqueous myoglobin solution was acidified by adding pre-cooled diluted hydrochloric acid $\left(0.1 \mathrm{M} \mathrm{HCl}_{(\mathrm{aq})}, 4{ }^{\circ} \mathrm{C}\right)$ and the $\mathrm{pH}$ value was adjusted to $2.5-3.0$ in order to denature myoglobin and thus to enable the release of heme. Heme was extracted from the aqueous solution by 2-butanone. The heme / 2-butanone solution was discarded and the aqueous apo-myoglobin solution was then purified using NAP columns in order to remove remaining 2-butanone and re-buffered in phosphate buffer (Kpi, pH 7.4) meanwhile. The protein concentration was determined spectrometrically by molar extinction coefficient of apomyoglobin at $280 \mathrm{~nm}\left(\varepsilon_{280}=15800 \mathrm{~cm}^{-1} \mathrm{~mol}^{-1} \mathrm{dm}^{3}\right)$. A solution of the apo-enzyme $\left(200 \mu \mathrm{L}, 60 \mu \mathrm{mol} \mathrm{dm}{ }^{-3}\right)$ in potassium phosphate buffer, $\mathrm{pH} 7$, was then mixed with BpyCu-hemeD1 6 conjugate (1.1 equiv., $330 \mu \mathrm{L}, 40$ $\mu \mathrm{mol} \mathrm{dm}{ }^{-3}$ ) and incubated for at least 24 hours at $4{ }^{\circ} \mathrm{C}$. Reconstituted enzymes were purified using ion exchange FPLC (AKTA purifier, Amersham Bioscience, MonoQ column, buffer A: $20 \mathrm{mmol} \mathrm{dm}^{-3}$ Tris A pH 8.3 and buffer B: $20 \mathrm{mmol} \mathrm{dm}^{-3}$ Tris $\mathrm{A}$ and $1.5 \mathrm{M} \mathrm{NaCl}$ using stepwise gradient (saved method: CHKHemenzyme.m01). The concentration of reconstituted myoglobin was determined spectrometrically by molar extinction coefficient of Soret band at $405 \mathrm{~nm}\left(\varepsilon_{405}=171000\right.$ $\mathrm{cm}^{-1} \mathrm{~mol}^{-1} \mathrm{dm}^{3}$ ).

Enantioselective catalytic reaction. An $1 \mathrm{~mL}$ of aqueous solution containing freshly distilled [cyclopentadiene 9] = $15 \mathrm{mmol} \mathrm{dm}^{-3}$, [aza-chalcone 8] $=1 \mathrm{mmol}$ $\mathrm{dm}^{-3}$, [catalytic conjugate] $=0.1 \mathrm{mmol} \mathrm{dm}^{-3}$ in phosphate buffer ( $\mathrm{pH}$ 7.4) was incubated under orbital shaking for 72 hours. The resulting reaction mixtures were then extracted with diethyl ether and were subjected to chiral-HPLC analysis (Daicel ODH, Hexane/IPA $=80 /$ 20, flow rate: $0.9 \mathrm{~mL} / \mathrm{min}$ ). The retention time of the products in the chiral-HPLC analysis was assigned according to the previously. The exo-isomers appeared at the retention time of 7.1 and 7.5 minutes while the endo-isomers appeared at the retention time of 8.1 and 9.2 minutes. The enantiomeric excess was estimated from the peak area in the chiral-HPLC chromatogram. The product conversion was estimated from the peak areas in the chiral-HPLC chromatogram based on the following formula:

$$
\text { conv. }(\%)=\frac{\text { area } P}{\frac{\operatorname{area} S}{c}+\operatorname{area} P} \cdot 100 \%
$$

Where area $P$ is the total peak area of the product of the reaction, area $S$ is the peak area of the starting material and $c$ is the correction factor determined to be 1.21 .

Supplementary Materials. Supporting informations to the paper are enclosed to the electronic version of the article. These data can be found on the website of Croatica Chemica Acta (http://public.carnet.hr/ccacaa).

Acknowledgements. This work was partially supported by the Zentrum für Angewandte Chemische Genomik (ZACG), a joint research initiative founded by the European Union and the Ministry of Innovation and Research of the state Northrhine Westfalia, the project SMD in the course of FP7-NMP2008-SMALL-2, founded by European Comission, and KIT Excellence Intitiative 2006-2011, project A5.7. C.-H.K. acknowledges support through the International Max-Planck Research School in Chemical Biology, Dortmund, and a student fellowship from Deutscher Akademischer Austauschdienst (DAAD). We would like to thank Prof. M. Christmann and his coworkers for help with the chiral HPLC analysis. 


\section{REFERENCES}

1. C. Letondor and T. R. Ward, Chembiochem. 7 (2006) 1845-1852.

2. H. B. Dunford, Heme Peroxidases, Wiley, New York, 1999.

3. I. Fridovich, Protein Sci. 7 (1998) 2688-2690.

4. (a) J. Zhuang, J. H. Amoroso, R. Kinloch, J. H. Dawson, M. J. Baldwin, and B. R. Gibney, Inorg. Chem. 43 (2004) 8218-8220; (b) Y. Lu, S. M. Berry, and T. D: Pfister, Chem. Rev. 101 (2001) 3047-3080; (c) Y. Lu, Inorg. Chem. 45 (2006) 9930-9940.

5. Y. Lu, Curr. Opin. Chem. Biol. 9 (2005) 118-126.

6. L: Fruk, C. H. Kuo, E. Torres, and C. M. Niemeyer, Angew. Chem. Int. Ed. Engl. 48 (2009) 1550-1574.

7. T. Havashi and Y. Hisaeda, Acc. Chem. Res. 35 (2002) 35-43.

8. I. Hamachi, S. Tanaka, S. Tsukiji, S. Shinkai, and S. Oishi, Inorg. Chem. 37 (1998) 4380-4388.

9. M. Skander, N. Humbert, J. Collot, J. Gradinaru, G. Klein, A. Loosli, J. Sauser, A. Zocchi, F. Gilardoni, and T. R. Ward, J. Am. Chem. Soc. 126 (2004) 14411-14418.

10. M. E. Wilson and G. M. Whitesides, J. Am. Chem. Soc. 100 (1978) 306-307.

11. (a) J. Collot, J. Gradinaru, N. Humbert, M. Skander, A. Zocchi, and T. R. Ward, J. Am. Chem. Soc. 125 (2003) 9030-9031; (b) G. Klein, N. Humbert, J. Gradinaru, A. Ivanova, F. Gilardoni, U. E. Rusbandi, and T. R. Ward, Angew. Chem. Int. Ed. Engl. 44 (2005) 7764-7767.

12. M. T. Reetz and N. Jiao, Angew. Chem. Int. Ed. Engl. 45 (2006) 2416-2419.

13. J. Podtetenieff, A. Taglieber, E. Bill, E. J. Reijerse, and M. T. Reetz, Angew. Chem. Int. Ed. Engl. 49 (2010) 5151-5155.

14. (a) G. Roelfes and B. L. Feringa, Angew. Chem. Int. Ed. Engl. 44
(2005) 3230-3232; (b) G. Roelfes, A. J. Boersma, and B. L. Feringa, Chem. Commun. (Camb) 2006 635-637; (c) A. J. Boersma, J. E. Klijn, B. L. Feringa, and G. Roelfes, J. Am. Chem. Soc. 130 (2008) 11783-11790.

15. (a) A. J. Boersma, R. P. Megens, B. L. Feringa, and G. Roelfes, Chem. Soc. Rev. 39 (2010) 2083-2092; (b) R. P. Megens and G. Roelfes, Org. Biomol. Chem. 8 (2010) 1387-1393.

16. A. J. Boersma, B. L. Feringa, and G. Roelfes, Angew. Chem. Int. Ed. Engl. 48 (2009) 3346-3348.

17. D. Coquiere, B. L. Feringa, and G. Roelfes, Angew. Chem. Int. Ed. Engl. 46 (2007) 9308-9311.

18. C. H. Kuo, L. Fruk, and C. M. Niemeyer, Chem. Asian. J. 4 (2009) 1064-1069.

19. L. Fruk and C. M. Niemeyer, Angew. Chem. Int. Ed. Engl. 44 (2005) 2603-2606.

20. H. Kitagishi, K. Oohora, H. Yamaguchi, H. Sato, T. Matsuo, A. Harada, and T. Hayashi, J. Am. Chem. Soc. 129 (2007) 10326-10327.

21. (a) H. Ogoshi and T. Mizutani, Curr. Opin. Chem. Biol. 3 (1999) 736-739; (b) H. Sato, T. Hayashi, T. Ando, Y. Hisaeda, T. Ueno, and Y. Watanabe, J. Am. Chem. Soc. 126 (2004) 436-437.

22. B. M. Hoffman and D. H. Petering, Proc. Natl. Acad. Sci. USA 67 (1970) 637-643.

23. A. D. Ryabov, Y. N. Firsova, A. Ershov, and I. A. Dementiev, J. Biol. Inorg. Chem. 4 (1999) 175-182.

24. I. Hamachi, S. Tsukiji, S. Shinkai, and S. Oishi, J. Am. Chem. Soc. 121 (1999) 5500-5506.

25. (a) S. Otto, F. Bertoncin, and J. B. F. N. Engberts, J. Am. Chem. Soc. 118 (1996) 7702-7707; (b) G. K. van Der Wel, J. W. Wijnen, and J. B. Engberts, J. Org. Chem. 61 (1996) 9001-9005.

26. C. S. Marvel, L. E. Coleman, and G. P. Scott, J. Org. Chem. 20 (1955) 1785-1792. 